\section{Mauritius Plants}

THE flora of Mauritius is of great interest on account of the geographical position of the Mascarenes, their relation to the great land masses of the Old World and the high endemism of the species. Unfortunately, the remnants of the original vegetation are fast disappearing. It is therefore very necessary to obtain adequate and critical herbarium material upon which must depend the advancement of know. ledge of the flora. A complete list of the flowering plants in the herbarium of the Mauritius Institute, compiled by R. E. Vaughan, forms the subject of the first part of a now publication (Mauritius Institute Bulletin) dealing with the taxonomy and ecology of the flora and fauna of the Mascarenes. About eight hundred species are listed, many of which are introduced weeds. Attention is directed to the urgency of acquiring additional material in many of the more interesting genera such as Eugenia, Diospyros (ebony) and Tambourissa, at present inadequately represented in the collection. Further material is also required of the native orchids, of which there were probably more than eighty species in the island, though many have already become extinct owing to the destruction of the large trees on which they were epiphytic.

\section{Fusible Metals}

IN No. 5, Series B, of the Technical Publications of the International Tin Researeh and Development Council, E. J. Daniels summarizes existing knowledge of the fusible metals containing tin. The mechanical and creep properties of these materials are dealt with, together with their 'castability', corrosion and applications. Among the latter are mentioned their uses in automatic safety devices for fire alarms, ets. as solders and seals, for making foundry patterns and for the production of hollow bodies by electrodeposition, as fillings for thin-walled tubes to prevent buckling during bending, as tempering baths for steel tools, as matrix alloys for mounting dies and punches, for the metallization of wood and for a number of research purposes.

\section{Special Libraries and Information Bureaux}

THE report of the proceedings at the fourteenth Annual Conference of the Association of Special Libraries and Information Bureaux at Cambridge last September has now appeared. It contains full reports of the discussions on technical translating, and the uses of micro-photographic processes in documentation, as well as the other papers given at the Conference, including one by Mr. B. M. Headicar containing a number of practical notes on the storage of pamphlets and the preservation and restoration of books and documents. In addition to its value as a permanent record of the proceedings at the Conference, the report indicates the wide range of interests of A.S.L.I.B.

\section{Science Abstracts}

The volume for 1937 devoted to physics has 1,504 pages, covering 5,494 abstracts, a subject index of 215 pages, an apparatus and instrument index of 24 pages and an author index of 78 pages. The volume for electrical engineering has 934 pages, 3,252 abstracts, a subject index of 121 pages and an author index of 48 pages. In pages and abstracts each volume is about 7 per cent less than that for 1936 , but continues to be indispensable to research workers and all who wish to keep up to date in the subject with which it deals. The system of indexing in the physics volume greatly facilitates quick and easy reference.

\section{Rabbit Control in Australia}

ON Wardang Island, which lies to the west of Yorke Peninsula in South Australia, a field test is now in progress of the virus of myxomatosis, as an agent in reducing rabbit population. The marked specificity of the disease to the European wild rabbit (Oryctolagus) and its retention of virulence after passage through many hosts make it well worth trial in a country where rabbits constitute a pest everpresent, though varying in intensity. The test is on a small infested area of some ninety acres under strictly controlled conditions.

\section{Grocers' Company Scholarship}

THE Grocers' Company is offering a scholarship for the encouragement of original medical research into the causation of prevalent diseases or as to means of preventing premature death. The award, which is tenable for two years from September 1, is $£ 300$ for the first year and $£ 450$ for the second year, in addition to which the Council will grant up to $£ 150$ a year towards the cost of special apparatus required by the scholar. Candidates should not be more than thirty-five years of age and should send their applications to the Clerk, Grocers' Company Hall, London, E.C.2, before May 1.

\section{Two Astronomical Handbooks for 1938}

Flammarion's "Annuaire Astronomique" is a remarkable little handbook, and those responsible for it evidently take great pains that it shall include the latest information on astronomical data. For example, the list of double star orbits contains the latest ones published. A note is given by Lyot on the transit of Mercury, on June 24, 1937, across the sun's corona; the list contributed by Störmer of auroras seen from Norway is continued as far as October 1, 1937, and there are some new geophysical data comprising sudden radio fadings observed from November 26, 1936, to July 1, 1937. The utility of this handbook to the novice is illustrated by the three maps showing the star field of the variable star, o (Mira) Ceti, as seen respectively with the naked eye, a pair of binoculars, and a moderate-sized telescope. The "Anuario" of the Astronomical Observatory of Madrid contains information that is chiefly of use to those living in Spain or in adjacent latitudes. There are, however, other astronomical tables and explanations (in Spanish) of general interest. A short description is appended of graphical solutions of spherical triangles used in problems of positional astronomy. 